\title{
Actin, Cytoplasmic 2
}

National Cancer Institute

\section{Source}

National Cancer Institute. Actin, Cytoplasmic 2. NCI Thesaurus. Code C150162.

Actin, cytoplasmic 2 (375 aa, $\sim 42 \mathrm{kDa}$ ) is encoded by the human ACT G1 gene. This protein plays a role in cytoskeletal structure. 